\title{
Vaccination Rates and Adherence to Guidelines in Splenectomy Patients: An Observational Cross-sectional Study
}

\section{Splenektomi Yapılan Hastalarda Așılanma Oranları ve Kılavuzlara Uyum: Gözlemsel, Kesitsel Bir Çalıșma}

Nursel ÇALIK BAȘARAN'(IID), Lale ÖZIȘIK'(ID), Og̃uz Abdullah UYAROG̃LU'(IID), Mine Durusu TANRIÖVER'(IID),

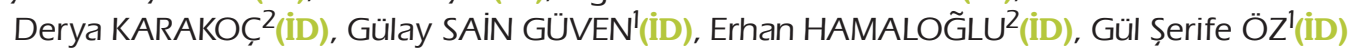

\footnotetext{
${ }^{1}$ Department of Internal Medicine, Hacettepe University School of Medicine, Ankara, Turkey

${ }^{2}$ Department of General Surgery, Hacettepe University School of Medicine, Ankara, Turkey
}

Cite this article as: Çalık Başaran N, Özışık L, Uyaroğlu OA, Tanrı̈̈ver MD, Karakoç D, Sain Güven G, et al. Vaccination rates and adherence to guidelines in splenectomy patients: an observational cross-sectional study. FLORA 2020;25(4):589-94.

\begin{abstract}
Introduction: Splenectomy, whatever the reason, is an absolute indication for vaccination against encapsulated bacteria in order to prevent overwhelming post-splenectomy infections. This study aimed to determine compliance to immunization guidelines for splenectomy in General Surgery Clinics.

Materials and Methods: In this observational cross-sectional study, we included patients who underwent splenectomy between April 2016 and April 2018, and recorded the patient data and vaccination status.

Results: Splenectomy was performed in 65 patients, 40 (61.5\%) were male and median age was 56 (19-90) years. Six of the operations were emergent, 21 were planned and 38 were urgent mostly due to solid organ malignancy. Only 14 (21.5\%) patients were vaccinated with Haemophilus influenzae, meningococcal and pneumococcal vaccines according to the guidelines ( $\geq 2$ weeks before the operation). 14 of the 21 patients (66.6\%) who underwent planned splenectomy were vaccinated appropriately.

Conclusion: Compliance with vaccination guidelines was low before splenectomy operations. There is a room for improvement particularly for patients undergoing elective splenectomy. A patient-centered team strategy is required to vaccinate patients at the stage of splenectomy planning.
\end{abstract}

Key Words: Splenectomy; Immunization; Vaccination; Overwhelming post-splenectomy infections (OPSI) 


\title{
ÖZ \\ Splenektomi Yapılan Hastalarda Așılanma Oranları ve Kılavuzlara Uyum: Gözlemsel, Kesitsel Bir Çalıșma
}

\author{
Nursel ÇALIK BAȘARAN', Lale ÖZIȘIK', Og̃uz Abdullah UYAROG̃LU', Mine Durusu TANRIÖVER', \\ Derya KARAKOÇ², Gülay SAIN GÜVEN' ${ }^{1}$, Erhan HAMALOG̃LU², Gül Șerife ÖZ1
}

\footnotetext{
${ }^{1}$ Hacettepe Üniversitesi Tıp Fakültesi, İç Hastalıkları Anabilim Dalı, Ankara, Türkiye

${ }^{2}$ Hacettepe Üniversitesi Tıp Fakültesi, Genel Cerrahi Anabilim Dalı, Ankara, Türkiye
}

Giriş: Nedeni ne olursa olsun, splenektomi, kapsüllü bakterilere karşı aşılama için mutlak bir endikasyondur. Bu çalışmada Genel Cerrahi Kliniklerinde splenektomi için aşılama kılavuzlarına ne kadar uyulduğunun belirlenmesi amaçlanmıştır.

Materyal ve Metod: Bu gözlemsel, kesitsel çalışmada Nisan 2016 ile Nisan 2018 yılları arasında splenektomi yapılan hastalar ve aşılanma durumları hastane sistemi kayıtlarından retrospektif olarak toplanarak değerlendirilmiştir.

Bulgular: Splenektomi yapılmış olan toplam 65 hasta [25 kadın/40 erkek, ortanca yaş 56+/-17 (19-90)] çalışmaya alındı. Operasyonlardan 6'sının acil, 21 'inin planlanmıs ve 38'inin çoğunlukla solid organ malignitesi nedeniyle yapıldığı görülmüştür. Sadece 14 (\%21.5) hastanın kılavuzlara uygun şekilde (operasyondan $\geq 2$ hafta önce) Haemophilus influenzae, meningokok ve pnömokok aşıları ile aşılandı̆̆ı belirlenmiştir. Planlı splenektomi yapılan 21 hastanın ise 14'ünün (\%66.6) uygun şekilde aşılandığı görülmüştür.

Sonuç: Splenektomi ameliyatlarından önce aşılama kurallarına uyumun düşük olduğu dikkati çekmektedir. Özellikle elektif splenektomi yapılan hastalar için aşılanma oranlarının iyileştirilmesi gerekmektedir. Bunun için splenektomi planlanan hastalar, hasta-merkezli multidisipliner bir yaklaşım ile değerlendirilmeli ve bu aşamada eksik aşılar tamamlanmalıdır.

Anahtar Kelimeler: Splenektomi; Immunizasyon; Aşılama; Splenektomi sonrası infeksiyonlar

\section{INTRODUCTION}

Splenectomy renders patients prone to invasive infections, especially to those of encapsulated microorganisms, namely Streptococcus pneumoniae, Haemophilus influenzae and Neisseria meningitidis. Overwhelming post-splenectomy infections (OPSI) are life-threatening conditions, characterized by invasive infections leading to fulminant sepsis and death; with a fatality rate of $50 \%[1,2]$. Most OPSI cases occur in the first year following splenectomy but the infection risk can subside for 20 years or more, with an estimated life time risk of $5 \%^{[3,4]}$. Frequency of OPSIs have been dramatically diminished with the vaccination of patients, planned to undergo splenectomy, against the encapsulated microorganisms ${ }^{[5,6]}$. Therefore, regardless of the indication for splenectomy, all patients should be vaccinated, preferably at least two weeks before the operation. The principles of vaccinating patients before splenectomy are well-defined by universal and national guidelines ${ }^{[7]}$. However, real life experience regarding vaccination rates and adherence to guidelines is not well-evaluated. In this case series, we aimed to determine whether the splenectomized received recommended vaccines within the recommended time interval.

\section{MATERIALS AND METHODS}

We retrospectively recruited medical information on all adult patients ( $\geq 18$ years old) who underwent splenectomy in Hacettepe University Hospital, General Surgery wards, between $1^{\text {st }}$ of April 2016 and $30^{\text {th }}$ of April 2018. All patients who survived at least 48 hours after surgery were included into the study. The study was conducted in accordance with the Declaration of Helsinki and after obtaining the approval of the Hacettepe University Ethical Committee (Approval number: GO 16/271-13, date: 19.04.2016). Following institutional ethical board approval, we screened the medical records, electronic files and vaccination histories of all patients for sociodemographic and medical data, date of splenectomy, indication for splenectomy, and the vaccines given before or on the operation day or after the operation. Splenectomy operations were grouped as 
"emergent", "urgent" or "planned" according to the underlying diseases and surgery timing after diagnosis. Surgeries performed in 24 hours due to splenic trauma or hemorrhage were referred to as "emergent"; those performed in less than 2 weeks after diagnosis and those performed more than 2 weeks after the medical decision for splenectomy were grouped as "urgent" or "planned", respectively. Time to vaccination was determined until discharge or in-hospital exitus. Vaccination status was assumed to be "proper immunization" if vaccination for $S$. pneumoniae, $H$. influenzae and $N$. meningitidis were performed $\geq 2$ weeks preceding the surgery or before the patient was discharged from the hospital.

\section{Statistics}

Data were analyzed using SPSS ver. 21.0 (SPSS INC., Chicago, IL, USA) software. Descriptive analyses included frequency and percent distributions. Continuous numerical data were analyzed for normal distribution; normally distributed data were presented as mean \pm standard deviation (SD), and median (minimum-maximum) were presented if normality was not assumed. Distribution of vaccination status with regards to indication for splenectomy was tested using Chi-square or Fisher's exact test, as appropriate. Type 1 error was set at 0.05 for all analyses.

\section{RESULTS}

A total of 65 patients underwent splenectomy between $1^{\text {st }}$ of April 2016 and $30^{\text {th }}$ of April 2018 in General Surgery wards. Medical records were obtained for all eligible patients. Of the patients, $40(61.5 \%)$ were males and median age was 56 (19-90) years. 6 of the operations were "emergent", 21 were "planned" and 38 were "urgent" in type; majority of the cases being related to solid organ malignancies (Table 1). $47(72.3 \%)$ of the patients were vaccinated with at least one type of the vaccines. Proper immunization (for all 3 infections) was detected in only $14(21.5 \%)$ patients, all of whom being vaccinated $\geq 2$ weeks before a planned operation; and 3 (4.6\%) patients had both meningococcal

\section{Table 1. Characteristics of the patients who underwent splenectomy}

\begin{tabular}{lc} 
Variable & Number (percentage, \%) \\
\hline Age; years* & $56(19-90)$ \\
Gender; male & $40(61.5)$ \\
Underlying disorders & \\
$\quad$ Solid organ malignancy & $38(58.5)$ \\
Hematological diseases, non-malignant & $17(26.2)$ \\
Hematological diseases, malignant & $5(7.7)$ \\
Trauma & $3(4.6)$ \\
Cyst & $1(1.5)$ \\
Hypersplenism & $1(1.5)$ \\
Splenectomy status & \\
Planned & $21(32.3)$ \\
Urgent & $38(58.5)$ \\
Emergency & $6(9.2)$ \\
Immunization status & \\
Pneumococcal vaccine, total & $47(72.3)$ \\
Meningococcal vaccine, total & $17(26.2)$ \\
Haemophilus influenzae vaccine, total & $14(21.5)$ \\
Proper immunization** & $14(21.5)$ \\
\hline * Median (minimum-maximum). & \\
** Proper immunization means vaccination against three encapsulated microorganism. & \\
&
\end{tabular}


and pneumococcal vaccine. Thirty (46.1\%) patients were immunized only with pneumococcal vaccine on the operation day. It was remarkable that $18(27.6 \%)$ patients were not vaccinated with any of the 3 vaccines, whilst the majority had solid malignancies and one had common variable immunodeficiency (CVID). All of the patients with a history of proper vaccination had a planned splenectomy. On the contrary, 7 patients with a planned splenectomy received vaccination less than appropriate: 4 had pneumococcal vaccine only and two others received meningococcal and pneumococcal vaccines. Most of the patients (82.2\%) received 23-valent pneumococcal polysaccharide vaccine, while the rest received 13-valent conjugated pneumococcal vaccine.

In-hospital mortality was $9.2 \%(6 / 65)$ and all had underlying advanced solid malignancies. None of the participants (including those deceased) had invasive infections due to one of these three vaccine-preventable organisms during hospitalization.

Proper immunization rates were statistically significantly higher among those with a planned surgery compared to their counterparts $(66.6 \%$ versus none, respectively, $\mathrm{p}<0.001$ ); similarly, proper vaccination was significantly more common among patients with hematological disorders than among those with solid organ disorders (59.1\% vs $2.3 \%$, respectively, $\mathrm{p}<0.001)$. Vaccination status was not significantly associated with mortality.

\section{DISCUSSION}

Splenectomy is usually performed due to trauma, malignant or benign hematological diseases, solid malignancies and portal hypertension. The underlying condition and the indication differ by years and in/between countries. Trauma-related splenectomy rates are higher in low-income countries and during war periods, with proportions reaching up to $50-75 \%$ of all cases ${ }^{[8,9]}$. Trauma is less prevalent in high-income countries due to low incidence and splenic preservation techniques. Hematological diseases are decreasing due to improvement in medical therapy choices, but in high-income countries nearly $30 \%$ of the splenectomies are due to hematological diseases, mostly non-malignant ${ }^{[10,11]}$. Solid organ malig- nancies constitute an increasing percentage of indications for splenectomy, as much as 20-30\%. In our study, solid organ malignancy was the leading underlying disease, followed by hematological diseases. Portal hypertension is a prevalent indication for splenectomy, but, was not present in our case series given that portal vein embolization is the preferred technique of therapy in our hospital for such patients.

Both global and national guidelines recommend proper vaccination of splenectomized patients to avoid OPSI, the most important complication after splenectomy. After proper vaccination interventions, rates of OPSI significantly diminished in time $e^{[3,11,12]}$. Ejstrud et al. have reported significantly reduced risk of bacteremia with vaccination in a cohort of 561 splenectomy patients ${ }^{[12]}$. Dendle et al studied 2472 splenectomized patients between the years 1998-2006, reporting serious bacterial infections, predominantly due to gram negatives. This study also revealed that OPSI due to three vaccine preventable pathogens diminished after proper vaccination practices ${ }^{[11]}$.

Our case series of splenectomized patients of a tertiary care university hospital revealed that proper vaccination practices are not as high as expected and timing is not always appropriate. Nearly one-fourth of all participants received none of the three vaccines suggested by the guidelines for this group of patients. Proper vaccination was performed only in two-thirds of the patients undergoing "planned" splenectomies. Pneumococcal vaccine was the mostly utilized vaccine. The general practice was vaccinating the patients on the operation day, if had not been done in the preceding 2 weeks.

This study provided evidence for the quality gap in our daily clinical practice with splenectomized patients. In this case series, vaccination rates among splenectomy patients against pneumococci, $H$. influenzae and meningococci were $72.3 \%, 21.5 \%$ and $26.2 \%$, respectively. Few studies have pointed out poor immunization practices and adherence to vaccination guidelines in this patient group ${ }^{[13,14]}$. Ramachandra et al. have reported that 30 of the 76 splenectomy patients were vaccinated against three pathogens, and $72 \%$ of patients received at least one vaccine ${ }^{[14]}$. 
Nived et al. have reported that vaccination against pneumococci, $H$. influenzae and meningococci were $63.3 \%, 51.9 \%$ and $22.8 \%$, respectively; whereas; another study from Netherlands has reported rates of $85.4 \%, 39.4 \%$, and $32.3 \%$, respectively ${ }^{[13,15,16]}$. A study from Poland has reported pneumococci, $H$. influenzae and meningococci vaccination in 20\%, 9.4\% and 3.5\% of splenectomy cases, respectively. Sabatino et al. have recently reported that $68 \%$ of the patients who had splenectomy had at least one vaccination but the proper vaccination rate is not higher than 34\%[17]. All findings together suggest that vaccination status among splenectomized patients is not as good as that recommended by the guidelines, with a wide range of vaccination rates and our vaccination rates fell into this range. At this point, it is important to note the reasons underlying low vaccination rates in this group.

Our center is a reference center for major surgical operations, such as Whipple operation for solid malignancies. Hence, our cases mostly had solid gastrointestinal system malignancies, requiring "urgent" splenectomy procedures. This may, at least partially, explain missing vaccinations prior to surgeries. However, even when vaccination preceding splenectomies, vaccines other than pneumococcal vaccine were mostly missing. This study was not designed to measure doctors' attitudes for vaccination or barriers resulting in the low vaccine coverage rates. Our in-hospital observations and informal data gathered from various surgeons in the hospital points at the fact that unavailability of the vaccines in the hospital and country is the most important barrier for vaccination. There is limited literature on the efficacy of implementing "clinical practice guidelines" or tools like "splenectomy vaccination kits" for improvement of vaccination rates ${ }^{[5,18]}$. Long-term registry systems providing education, clinical guidance and annual vaccination reminders to splenectomy patients and healthcare providers have shown to be effective in increasing adherence rates to guidelines and, recently, a 69\% risk reduction in infections has been shown ${ }^{[19,20]}$. Further prospective studies, combined with qualitative evidence on barriers to vaccination of splenectomy patients are clearly warranted. Data on availability, accessibility (including cost of vaccines) and acceptability of individual vaccines; vaccination place and procedures; contraindications for vaccines (if any); patients' information and follow-up before/at the time of/after splenectomy on necessity for vaccination to prevent specific infections might be collected in future studies to fulfill the missing evidence in the literature.

\section{Study Limitations}

Our study is descriptive in nature, collected data retrospectively and the study sample is restricted to the number of splenectomy cases in the hospital. Absence of a printed or electronic vaccination card across the continuum of care and use of self-reports for information on vaccinations before hospital admission might have led to information bias. External validity of our findings should also be evaluated cautiously. Yet, our findings revealed that routine practice on vaccination is far from expected and various potential barriers (including availability and accessibility of vaccines, patient education and awareness, doctors' thought and attitudes on necessity for a timely vaccination of all patients) should be studied further in larger and heterogeneous groups. Our finding of higher rates of proper vaccination among individuals undergoing planned splenectomies suggests that accessibility to vaccine might have influenced vaccination status. Yet, this finding needs to be confirmed in future qualitative studies. Information on several factors (including, socioeconomic status, educational attainment, comorbidities, contraindications for vaccination) that might have confounding role in the analysis should be collected in future studies. Last but not the least, our vaccination history was obtained till the time of discharge from hospital or in-hospital death (whichever came first), restricting our capability to detect vaccinations completed after discharge. This might have somewhat underestimated the true rate of vaccination among patients with early discharges.

\section{CONCLUSION}

Vaccination of patients undergoing splenectomy is useful for preventing OPSIs and physicians are recommended to follow guidelines for it. However, there is room for improvement to 
attain the best practice for vaccinating such patients. Further research on potential barriers for vaccination of splenectomized patients are clearly warranted. Reading the runes, a patient-centered team strategy is required to prepare required vaccinations at the stage of splenectomy planning.

\section{ACKNOWLEDGEMENTS}

There isn't any external editing support by any agents and agencies.

\section{ETHICS COMMITTEE APPROVAL}

The approval for this study was obtained from Hacettepe University Ethical Committee (Decision no: GO 16/271-13, Date: 19.04.2016).

\section{CONFLICT of INTEREST}

The authors declare that they have no conflict of interest.

\section{AUTHORSHIP CONTRIBUTIONS}

Concept/design: NÇB, LÖ, DK, GSG

Analysis/interpretation: NÇB, EH, OAU, SGÖ

Data acquisition: NCCB,LÖ, DK, EH, MDT

Writting: NCCB, MDT, OAU

Final approval: NÇB, LÖ, OAU, MDT, DK, GSG, EH, ȘGÖ

\section{REFERENCES}

1. Werner S, Winstedt D, Kander T. 29-year-old man treated with splenectomy died of pneumococcal sepsis. Important that pneumococcal vaccination of splenectomised is not forgotten. Lakartidningen 2012;109:1404-5.

2. Holdsworth RJ, Irving AD, Cuschieri A. Postsplenectomy sepsis and its mortality rate: actual versus perceived risks. $\mathrm{Br} J$ Surg 1991;78:1031-8.

3. Kristinsson SY, Gridley G, Hoover RN, Check D, Landgren O. Long-term risks after splenectomy among 8,149 cancer-free American veterans: a cohort study with up to 27 years follow-up. Haematologica 2014;99:392-8.

4. Waghorn DJ. Overwhelming infection in asplenic patients: current best practice preventive measures are not being followed. I Clin Pathol 2001;54:214-8.

5. Mitchell TA, Wallum TE, White CE, Sanders KE, Aden JK, Bailey JA, et al. Evaluation of the effectiveness of the 2008 postsplenectomy vaccination joint theater trauma system clinical practice guideline. Mil Med 2015;180:1170-7.

6. Boyle S, White RH, Brunson A, Wun T. Splenectomy and the incidence of venous thromboembolism and sepsis in patients with immune thrombocytopenia. Blood 2013;121:4782-90.
7. Kim DK, Riley $L E$, Harriman $K H$, Hunter P, Bridges $C B$, Advisory Committee on Immunization P. Recommended immunization schedule for adults aged 19 years or older, United States, 2017. Ann Intern Med 2017;166:209-19.

8. Bisharat N, Omari H, Lavi I, Raz R. Risk of infection and death among post-splenectomy patients. I Infect 2001:43:182-6.

9. Khamechian T, Alizargar J, Farzanegan M. Pattern of splenectomy indications in kashan shahid-beheshti hospital: a 5-year study. Arch Trauma Res 2013;1:180-3.

10. Edgren $G$, Almqvist R, Hartman M, Utter GH. Splenectomy and the risk of sepsis: a population-based cohort study. Ann Surg 2014;260:1081-7.

11. Dendle C, Sundararajan V, Spelman $T$, Jolley $D$, Woolley I. Splenectomy sequelae: an analysis of infectious outcomes among adults in Victoria. Med J Aust 2012;196:582-6.

12. Ejstrud $P$, Kristensen B, Hansen IB, Madsen KM, Schonheyder HC, Sorensen HT. Risk and patterns of bacteraemia after splenectomy: a population-based study. Scand I Infect Dis 2000;32:521-5.

13. Nived $P$, Jorgensen $C S$, Settergren $B$. Vaccination status and immune response to 13-valent pneumococcal conjugate vaccine in asplenic individuals. Vaccine 2015;33:1688-94.

14. Kealey GP, Dhungel V, Wideroff MJ, Liao J, Choi K, Skeete $D A$, et al. Patient education and recall regarding postsplenectomy immunizations. I Surg Res 2015;199:580-5.

15. Ramachandra J, Bond A, Ranaboldo C, Cullis J. An audit of post-splenectomy prophylaxis--are we following the guidelines? Ann R Coll Surg Engl 2003;85:252-5.

16. Kuchar E, Nitsch-Osuch A, Stolarczyk C, Kurpas D, Zycinska $K$, Wardyn $K$, et al. Immunization coverage against capsular bacteria in splenectomized patients. Adv Exp Med Biol 2013;788:139-45.

17. Di Sabatino A, Lenti MV, Tinozzi FP, Lanave M, Aquino I, Klersy $C$, et al. Vaccination coverage and mortality after splenectomy: results from an Italian single-centre study. Intern Emerg Med 2017;12:1139-47.

18. Meier-Stephenson V, McNeil S, Kew A, Sweetapple J, Thompson $K$, Slayter K. Effects of a pharmacy-driven perisplenectomy vaccination program on vaccination rates and adherence to guidelines. Can J Hosp Pharm 2014;67:262-7.

19. Arnott A, Jones P, Franklin LJ, Spelman D, Leder K, Cheng AC. A registry for patients with asplenia/hyposplenism reduces the risk of infections with encapsulated organisms. Clin Infect Dis 2018;67:557-61.

20. Wang J, Jones $P$, Cheng $A C$, Leder $K$. Adherence to infection prevention measures in a statewide spleen registry. Med I Aust 2014;200:538-40.

\section{Address for Correspondence/Yazıșma Adresi}

Uzm. Dr. Oğuz Abdullah UYAROĞLU

Hacettepe Üniversitesi Tip Fakültesi,

İc Hastalıkları Anabilim Dalı,

Ankara-Türkiye

E-mail: oguzuyaroglu@hotmail.com 